\title{
Free and attached proteolytic activity in water environments
}

\author{
José Vives Rego*, Gilles Billen, Anne Fontigny and Martine Somville \\ Laboratoire d'Océanographie, University of Brussels, 50, avenue F.-D. Roosevelt, B-1050 Brussels, Belgium
}

\begin{abstract}
Size distribution of exoproteolytic activity, as detected by hydrolysis of L-Leucyl- $\beta$ Naphthylamide, was studied by differential filtration, ultrafiltration and centrifugation, on natural and enriched samples from the Southern Bight of the North Sea and the Scheldt estuary. Effects of sonication and treatment with Triton X-100 on this size distribution were also investigated. Most exoproteolytic activity in the aquatic environments studied is bound to the envelopes of bacteria. The small fraction ( 0 to $30 \%$ ) of total exoproteolytic activity passing a $0.2 \mu \mathrm{m}$ filter probably consists of cell fragments: produced upon lysis of bacteria instead of being actively excreted.
\end{abstract}

\section{INTRODUCTION}

It has long been recognized that high-molecularweight organic compounds, although they form the bulk of organic matter produced in natural environments, cannot be directly taken up by bacteria, unless first exoenzymatically hydrolyzed (Rogers, 1961; Billen, 1984). Depending on the bacterial strain, exoenzymes can either be produced as free dissolved molecules diffusing in the medium, or remain bound to the external side of the microorganism envelopes ( $\mathrm{Pol}-$ lock, 1962).

Although free exoenzymes have been detected in sea water (Hanson and Kim, 1970; Kim and Zobell. 1974). Hollibaugh and Azam (1983) have recently shown that microbial degradation of protein in sea water is particle-associated. They suggested that exoproteases of marine bacteria are structurally bound to cell membranes and that amino acids derived from proteins do not completely mix with the free amino acids in the bulk-phase.

Recently, a very simple and sensitive method for determining both free and attached exoproteolytic enzymes in natural waters has been described by Somville and Billen (1983). We present here data, produced with this method, which provide new insights into the

\footnotetext{
- Present address: Departamento de Microbiologia, Facultad
de Biologia, Universidad de Barcelona, Av. Diagonal 645
Barcelona-28, Spain

- Present address: Departamento de Microbiologia, Facultad
de Biologia, Universidad de Barcelona, Av. Diagonal 645
Barcelona-28, Spain

- Present address: Departamento de Microbiologia, Facultad
de Biologia, Universidad de Barcelona, Av. Diagonal 645
Barcelona-28, Spain
}

free or attached nature of exoproteolytic activity (EPA) in natural waters.

\section{METHODS}

Proteolytic activity was assayed by following fluorimetrically the production of $\beta$-naphthylamine from L-Leucyl- $\beta$-naphthylamide, as described by Somville and Billen (1983). We defined the enzyme unit as the amount of enzyme catalysing the cleavage of 1 nmole $\beta$-naphthylamide min $^{-1}$.

(Methyl- ${ }^{3} \mathrm{H}$ )-thymidine incorporation into cold TCA insoluble fraction, measured as described by Fuhrman and Azam $(1980,1982)$, was used as an index of bacterial activity. Bacterial counts were obtained by epifluorescence microscopy after acridine orange staining, following the standard procedure of Hobbie et al. (1977). Cell disruption was performed by ultrasonicating $120 \mathrm{ml}$ samples, maintained in an ice bath, for 5 periods of 2 min, using a Branson Sonic S-75, adjusted at $4.2 \mathrm{~A}$. Treatment with Triton was performed by adding $0.5 \%$ Triton $\mathrm{X}-100$ and $0.1 \%$ antifoam-100 (Dow Corning) to $100 \mathrm{ml}$ samples and shaking with a kitchen mixer (type 'Waring blendor') for 3 periods of 1 min each.

Filtration of the samples was performed by gentle pressure filtration through Sartorius cellulose acetate $(0.2$ and $0.8 \mu \mathrm{m})$ or Nucleopore polycarbonate $(2 \mu \mathrm{m})$ membranes. It is well known that cellulose acetate 
filters can retain particles smaller than their rated pore size, while Nucleopore polycarbonate filters do not. Samples were centrifuged at room temperature with a $20 \mathrm{~cm}$ diameter rotor, at $2,500 \mathrm{~g}$ for $20 \mathrm{~min}$. Ultrafiltration experiments were done with Amicon ultrafiltration cells and membranes, under $4 \mathrm{~atm}$ nitrogen pressure.

Enrichment of sea water with albumin was made by adding a small amount of a filter sterilized solution of albumin in distilled water, in order to obtain an initial concentration of $40 \mathrm{mg} \mathrm{l}^{-1}$.

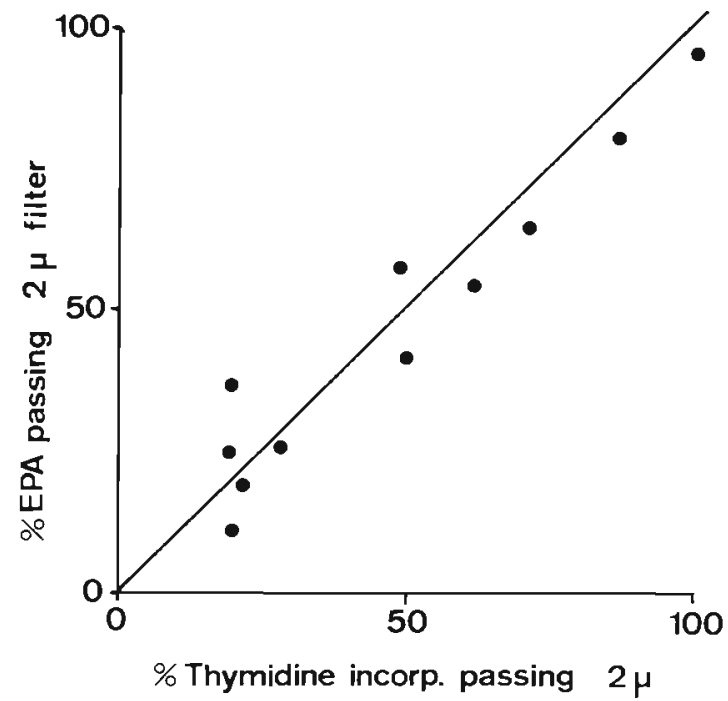

Fig. 1. Similarity of size fractionation pattern of exoproteolytic activity and thymidine incorporation into bacterial DNA. Percentage of exoproteolytic activity passing a $2 \mu \mathrm{m}$ membrane is plotted against the percentage of thymidine incorporation measured after filtration through $2 \mu \mathrm{m}$ membrane

\section{RESULTS}

\section{Size fractionation of proteolytic activity in natural samples}

Proteolytic activity, thymidine incorporation into cold TCA insoluble fraction and acridine orange bacterial counts were measured at several occasions from early 1982 to spring 1984 on natural samples from the Scheldt estuary and the southern bight of the North Sea. The range of values found in these 2 environments were respectively 4 to 30 and 1 to 30 enzymes units $1^{-1}$ for exoproteolytic activity; 2 to 250 and 0.3 to $60 \times$ $10^{-3}$ nmoles $\mathrm{l}^{-1} \mathrm{~h}^{-1}$ for thymidine incorporation; 1 to 10 and 0.1 to $3 \times 10^{9}$ bact $l^{-1}$.

Size fractionation of proteolytic activity was carried out on more than 100 samples by prefiltration through membranes of 2, 0.8 and $0.2 \mu \mathrm{m}$ porosity. Activity in 2 and $0.8 \mu \mathrm{m}$ filtrates ranged, respectively, from 100 to $10 \%$ and from 48 to $0 \%$ total activity, depending on the samples. A higher percentage of total activity in these fractions was generally found in open sea samples than in inshore or estuarine ones. This size fractionation pattern probably reflects either the size distribution of bacteria themselves or their binding with particles.

On some of the same samples, size fractionation of thymidine incorporation and bacterial numbers were also determined. Fig. 1 shows that the size fractiona-

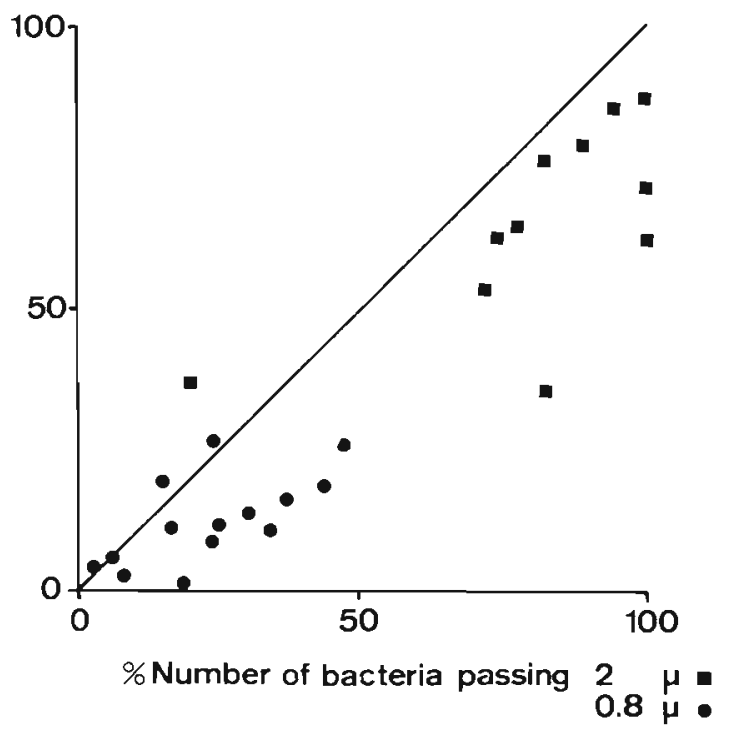

Fig. 2. Similarity of size fractionation pattern of exoproteolytic activity and of bacterial numbers. Percentage of exoproteolytic activity passing a $2 \mu \mathrm{m}(\boldsymbol{m})$ or a $.8 \mu \mathrm{m}(\bullet)$ filter is plotted against the percentage of bacterial numbers passing the same filters

tion pattern of exoproteolytic activity is quite similar to that of thymidine incorporation. It is also rather similar to the size fractionation pattern of bacterial numbers (Fig. 2), although the reduction in bacterial numbers by filtration is systematically lower than in exoproteolytic activity.

Activity in the $0.2 \mu \mathrm{m}$ filtrate of natural samples was generally a very low percentage of total activity, ranging from 0 to a maximum of $30 \%$. Situations like this observed by Somville and Billen (1983) in the Belgian coastal zone in June 1981, where most exoproteolytic activity passed a $0.2 \mu \mathrm{m}$ filter, were never again observed in 1982 and subsequent years. On 5 occasions, we performed differential ultrafiltration of samples where significant activity was found in the $0.2 \mu \mathrm{m}$ filtrate. The results showed that 94 to $100 \%$ of the 'free' activity is associated with particles of apparent molecular weight higher than 100,000 daltons. 


\section{Effect of organic enrichment}

When albumin is added to a sample of sea water, a rapid rise in bacterial numbers occurs. Exoproteolytic activity increases quite parallel (Fig. 3). During this rise, the fraction of exoproteolytic activity passing a $0.2 \mu \mathrm{m}$ filter remains very low. When the substrate is exhausted, on the other hand, both bacterial numbers and total exoproteolytic activity decrease rapidly. As no proliferation of flagellates was observed during cell counts, this decrease probably results from a rapid lysis of the cells, rather than from grazing by bacteriovores. At this stage, the fraction of exoproteolytic activity passing a $0.2 \mu \mathrm{m}$ filter increases up to $20 \%$. This strongly suggests that in these enrichment experiments, 'free' exoenzymatic activity is the result of death and lysis of the bacteria.

\section{Effect of centrifugation and sonication}

After centrifugation of natural sea water samples at $2,500 \mathrm{~g}$ for $20 \mathrm{~min}$, thymidine incorporation was reduced to zero and only 0 to $15 \%$ of total exoproteolytic activity was found remaining in the supernatant.

Sonication of samples as described in 'Methods'. reduces thymidine incorporation to 1 to $5 \%$ of the initial value while the level of exoproteolytic activity remained practically the same (Table 1). Size distribution of the activity, however, was modified, with higher percentage passing through 2 and $0.8 \mu \mathrm{m}$ filters. Exoproteolytic activity passing a $0.2 \mu \mathrm{m}$ filter remains low $(<3.5 \%$ of total activity). Also centrifugation of the sonicated samples results in the sedimentation of most ( 87 to $93 \%$ ) exoproteolytic activity. These results indicate that disruption of cells by sonication does not liberate important amounts of endocellular or periplasmic proteolytic enzymes detectable with the aminoacid- $\beta$-Naphthylamide test. All the activity detected is probably associated with exoenzymes attached to cell envelope fragments which do not pass a $0.2 \mu \mathrm{m}$ filter and can be sedimented by centrifugation.

\section{Effect of Triton X-100}

Vigorous shaking of the samples with the non-ionic detergent Triton X-100 generally does not reduce total proteolytic activity. In some instances, it even slightly enhances this activity (Table 1 ). This treatment always results in an increase of the fraction passing a $0.2 \mu \mathrm{m}$ filter (44 to $110 \%$ ) and remaining in the supernatant after centrifugation at $2,500 \mathrm{~g}$ for $20 \mathrm{~min}$ ( 65 to $85 \%$ ). Only a negligible fraction of this activity, however, pass an ultrafiltration membrane of 100,000 daltons,
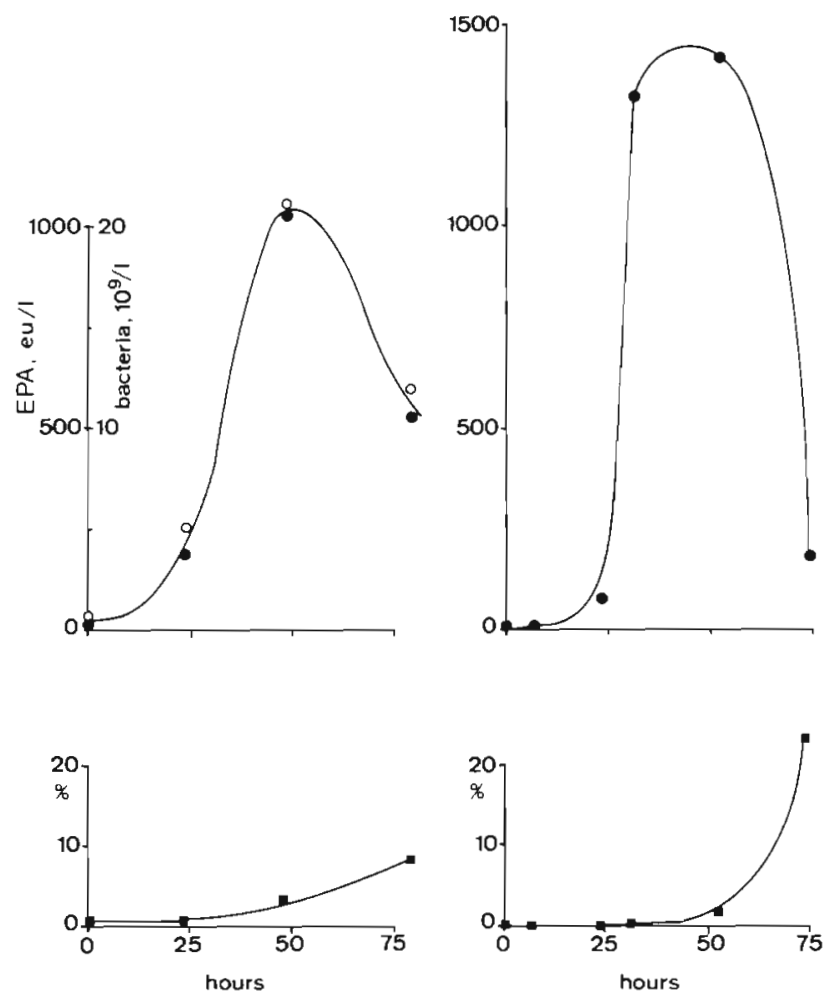

Fig. 3. Time course of exoproteolytic activity (•) and bacterial number (o) development after enrichment of 2 sea water samples with $40 \mathrm{mg} \mathrm{l}^{-1}$ albumin (above). Fraction of total exoproteolytic activity passing a $.2 \mu \mathrm{m}$ filter (below). Samples were collected in the Belgian coastal zone, in March 1984 (left) and in May 1984 (right)

indicating that the apparent molecular size of the enzymes responsible for the activity detected is higher than 100,000 .

\section{DISCUSSION}

Proteolytic enzymes include proteinase, amino-peptidases and carboxypeptidases (Mahler and Cordes, 1969; International Union of Biochemistry, 1978). The method developed by Somville and Billen (1983), using L-Leucyl- $\beta$-naphthylamide as a substrate, can detect proteinase and aminopeptidases. Particularly, in the case of bacteria, these enzymes generally exhibit a very broad or even no specificity with respect to the amino-acid residues, the peptide bond of which they hydrolyse. Our method can therefore be regarded as a significant index of total bacterial proteolytic activity.

Differential filtration and centrifugation of natural samples show that most ( 70 to $100 \%$ ) proteolytic activity in sea and estuarine environments is bound to particles.

Close similarity is observed between the size fractionation pattern of proteolytic activity and thy- 
Table 1. Effect of sonication and Triton X-100 on exoproteolytic activity in estuarine and sea water samples. Values expressed as $\%$ of untreated samples

\begin{tabular}{lcccc|}
\hline & Total & $\begin{array}{c}\text { Exoproteolytic activity } \\
\text { Filtrate } \\
<0.2 \mu \mathrm{m}\end{array}$ & $\begin{array}{c}\text { Centrifugated } \\
\text { (supernatant) }\end{array}$ & Thymidine incorporation \\
\hline Control & 100 & 0 & 0 & 100 \\
Sonication (1) (2) & $77-100$ & $0-3.5$ & $7.5-13$ & $2-5$ \\
Control & 100 & $0-15$ & 0 & 100 \\
Triton X-100(1) (3) & $80-110$ & $\mathbf{4 4 - 1 1 0}$ & $65-85$ & $6.5-45$ \\
(1) Treatment as described in methods & & & \\
(2) 4 independent experiments & & & & \\
(3) 9 independent experiments & & & \\
\hline
\end{tabular}

midine incorporation (Fig. 1). As thymidine incorporation has been recognized as a specific index of bacterial activity (Fuhrman and Azam, 1982), this strongly suggests that proteolytic enzymes are bound to growing bacteria themselves. The similarity with the size fractionation pattern of bacterial numbers is a little bit less evident, more bacteria passing a 2 or $0.8 \mu \mathrm{m}$ filter than does exoproteolytic activity (Fig. 2). This could result from the fact that bigger bacteria, or bacteria attached to particles, exhibit more exoproteolytic activity than do smaller or free bacteria.

Disruption of the cells by sonication results in the production of cell-envelope fragments which can be sedimented by centrifugation and to which proteolytic enzymes remain attached (Table 1 ). The non-ionic detergent Triton X-100 is known to solubilize cell-wall and membrane proteins (Schnaitman, 1971). Vigorous shaking has been shown to release capsular material from bacteria (Yuruwitz et al., 1971). Shaking samples with Triton X-100 and antifoam agent results in liberating previously attached proteolytic activity in a form which does not sediment upon centrifugation (Table 1). Although we cannot assess the respective roles of shaking. Triton and antifoam agent, these results strongly suggest that most proteolytic activity in natural water samples is structurally bound to the envelopes of bacteria. A similar mechanism has been established in the case of Cytophaga (Christison and Martin, 1971), Bacteroides (Blackburn and Hullah, 1974; Hazlewood and Edwards, 1981) and in rumen bacteria (Kopecny and Wallace, 1982). These findings support and extend the model of Hollibaugh and Azam (1983) for protein degradation by marine bacterioplankton. According to the translation-extrusion model (Glenn, 1976) exoproteins are translated on membrane bound ribosomes and extruded directly through the membrane as they are being synthesized. Such a model can explain our observation that Triton X-100 sometimes enhance exoproteolytic activity. This can occur by unmasking some already extruded exoenzymes remaining inactive inside the cell wall or the capsule.

A small fraction ( 0 to a maximum of $30 \%$ ) of total exoproteolytic activity in natural water is found, however, in the dissolved state. This fraction increase considerably in the declining phase of an enrichment culture (Fig. 3). Ultrafiltration clearly shows that this 'free' activity is associated with particles of apparent molecular weight higher than 100,000 daltons. The values reported in the literature for molecular weight of isolated proteases range from 20,000 to 60,000 daltons (Glenn, 1976; Blackburn and Hullah, 1982). Although we cannot exclude the possibility that some exoproteolytic enzymes have higher molecular weight, it is likely that no true free proteases are produced neither naturally in the water samples we observed, nor by the mechanical and physicochemical treatments we used. Instead, our results suggest that the exoproteolytic activity detected in the $<0.2 \mu \mathrm{m}$ fraction corresponds in most case to enzymes bound to cell envelope fragments produced upon lysis of bacteria instead of being actively excreted.

\section{LITERATURE CITED}

Billen, G. (1984). Heterotrophic utilization and regeneration of nitrogen. In: Hobbie, J. E., LeB Williams, P. J. (ed.) Heterotrophic activity in the sea. Plenum Press, New York, p. 313-355

Blackburn, T H., Hullah, W. A. (1974). The cell-bound protease of Bacteroides amylophilus H 18. Can. J. Microbiol. 20: $435-441$

Christison, J., Martin, M. (1971). Isolation and preliminary characterization of an extracellular protease of Cytophaga sp. Can. J. Microbiol. 17: 1207-1216

Fuhrman, J. A., Azam, F. (1980). Bacterioplankton secondary production estimates for coastal waters of British Columbia, Antarctica and California. Appl. environ. Microbiol. 39: 1085-1095 
Fuhrman, J. A., Azam, F. (1982). Thymidine incorporation as a measure of heterotrophic bacterioplankton production in marine surface waters: evaluation and field results. Mar. Biol. 66: 109--120

Glenn, A. R. (1976). Production of extracellular proteins by bacteria. A. Rev. Microbiol. 30: 41-62

Hanson, R. B., Kim, J. (1970). Activities of cell free enzymes dissolved in the marine environment. Bact. Proc. 1970: 27

Hazlewood, G. P., Edwards, R. (1981). Proteolytic activities of a rumen bacterium, Bacteroides ruminicola R8/4. J. gen Microbiol. 125: 11-15

Hobbie, J. E., Daley, R. J., Jasper, S. (1977). Use of Nucleopore filters for counting bacteria by fluorescence microscopy. Appl environ. Microbiol 33: 1225-1228

International Union of Biochemistry, Nomenclature Committee 1978. Enzyme Nomenclature. Academic Press, London, p. 296-348

Hollibaugh, J. T., Azam, F. (1983). Microbial degradation of dissolved proteins in seawater. Limnol. Oceanogr. 28: $1104-1116$

Kim, J., Zobell, C. E. (1974). Occurrence and activities of cellfree enzymes in oceanic environments. In: Colwell, R. R., Morita, R. Y. (ed.) Effect of the ocean environment on microbial activities. University Park Press, London, p. $368-385$
Kopecny, J., Wallace, R. J. (1982). Cellular location and some properties of proteolytic enzymes of rumen bacteria. Appl. environ. Microbiol. 39: 1059-1066

Mahler, H. R., Cordes, E. H. (1969). Biological chemistry. Harper and Row, p. 665-666

North, M. J. (1982). Comparative biochemistry of the proteinases of eucaryotic microorganisms. Microbiol. Rev. 46: $308-340$

Pollock, M. R. (1962). Exoenzymes. In: Gunsalus, I. C., Stanier, K. Y. (ed.) The bacteria, Vol. 4. Academic Press, London, p. 121-178

Rogers, H. J. (1961). The dissimilation of high molecular weight substances. In: Gunsalus, I. C., Stanier, R. Y, (ed.) The bacteria, Vol. 2. Academic Press, London, p. 121-178

Schnaitman, C. A. (1971). Solubilization of the cytoplasmic membrane of Escherichia coli by Triton X-100. J. Bacteriol. 108: 545-552

Somville, M., Billen, G. (1983). A method for determining exoproteolytic activity in natural waters. Limnol. Oceanogr. 28: 190-193

Yuruwitz, E. C., Ghalambor, M. A., Heath, E. C. (1971). The structure of Aerobacter aerogenes capsular polysaccharide. J. biol. Chem. 246: 5596-5606

This paper was presented by Professor T. Fenchel; it was accepted for printing on October 7,1984 